\title{
EFFICACY AND TOLERABILITY OF TRIFLURIDINE/TIPIRACIL IN PATIENTS WITH REFRACTORY METASTATIC COLORECTAL CANCER AT THE GENERAL HOSPITAL OF ŠIBENIK-KNIN COUNTRY
}

\author{
LANA JAJAC BRUČIĆ ${ }^{1}$, FILIP GRUBIŠIĆ-ČABO ${ }^{1}$, JOSIPA JOVIĆ ZLATOVIĆ ${ }^{1}$ and IVAN KREČAK ${ }^{1}$ \\ ${ }^{1}$ Department of Internal Medicine, General Hospital of Šibenik-Knin Country, Šibenik, Croatia
}

\begin{abstract}
Summary
In randomized clinical trials, trifluridine / tipiracil (TT) demonstrated beneficial effects on progression-free survival (PFS) and overall survival (OS) in patients with refractory metastatic colorectal cancer (mCRC). The aim of this unicentric study was to evaluate the efficacy and safety of TT in patients with refractory $\mathrm{mCRC}$ in everyday clinical practice. Treatment outcomes of 20 patients were retrospectively analyzed. The median OS was 6.25 months (range 1-18) and the median PFS was 3 months (range 2-13). The most common (80\%) side effect of TT was neutropenia and 35\% of patients had neutropenia grades 3 of 4 ; however, only two patients $(10 \%)$ had neutropenic fever and no deaths were attributable to neutropenia. In conclusion, treatment outcomes in this real-life study seem comparable to those from randomized clinical trials.
\end{abstract}

KEYWORDS: refractory metastatic colorectal cancer; colorectal cancer treatment; trifluridine/tipiracil

\section{INTRODUCTION}

Colorectal cancer is the third most commonly diagnosed malignancy and the fourth leading cause of cancer death in the world $(1,2)$. In Croatia it is third most common cancer in men and second in women(2). Despite treatment and diagnostic advances, the mortality rates of mCRC remain high, with a patient survival of 24-30 months(3-6). The treatment backbone for patients with mCRC is irinotecan- and oxaliplatin-based therapy in combination with fluoropyrimidines and molecular targeted therapy(5-8). Treatment options for $\mathrm{mCRC}$ after progression to standard therapy is limited. Also, it is important to emphasize that quality of life is an important outcome during the later-lines of therapy. Trifluridine/tipiracil (TT) is

Corresponding author: Lana Jajac Bručić, Department of Internal Medicine, General Hospital of Šibenik-Knin Country, Ulica Stjepana Radića 83, 22000 Šibenik, Croatia. e-mail: lana. jajac@gmail.com an orally administered cytotoxic agent approved for treatment of patients with refractory mCRC.

The aim of this unicentric study was to evaluate efficacy and safety of TT in patients with refractory $\mathrm{mCRC}$ in everyday clinical pratice.

\section{PATIENTS AND METHODS}

Treatment outcomes of patients with refractory mCRC at the General Hospital of Šibenik-Knin County from March 2018 to March 2021 were retrospectively analyzed. PFS was defined as the time from first TT application until disease progression, while OS was measured as the time from first TT application until death or the last follow-up visit. The results were presented by descriptive statistical methods and the survivals between the groups were compared with the Kaplan-Meier method and the log-rank test. Statistical calculations were performed with MedCale Software, version 20.008 (Ostend, Belgium) and p-values $<0.050$ were considered statistically significant for all presented. 
Table 1.

Patient characteristics

\begin{tabular}{|c|c|c|}
\hline & & $N(\%)$ \\
\hline \multirow[t]{2}{*}{ Age } & Median & 67 \\
\hline & Range & $53-83$ \\
\hline \multirow[t]{2}{*}{ Gender } & Male & $14(70)$ \\
\hline & Female & $6(30)$ \\
\hline \multirow[t]{3}{*}{ ECOG status } & 0 & $4(20)$ \\
\hline & 1 & $13(65)$ \\
\hline & 2 & $3(15)$ \\
\hline \multirow[t]{3}{*}{ Primary tumor location } & Rectum & $6(30)$ \\
\hline & Left colon & $10(50)$ \\
\hline & Right colon & $4(20)$ \\
\hline \multirow[t]{2}{*}{ RAS status } & Wild type & $3(15)$ \\
\hline & Mutation & $17(85)$ \\
\hline \multirow{2}{*}{$\begin{array}{l}\text { Time from diagnosis } \\
\text { of metastasis to initiation } \\
\text { of treatment }\end{array}$} & $>18$ month & $12(60)$ \\
\hline & $\leq 18$ month & $8(40)$ \\
\hline \multirow{3}{*}{$\begin{array}{l}\text { Number of previous lines } \\
\text { of therapy }\end{array}$} & 1 & 1 \\
\hline & 2 & 16 \\
\hline & $\geq 3$ & 3 \\
\hline
\end{tabular}

\section{RESULTS}

A total of 20 patients with $\mathrm{mCRC}$ were treated with TT; the median age was 67 years (range 53-83), and the majority were male (70\%). The patients were in good general condition (performance status $0-2)$. Ten patients $(50 \%)$ had left-sided cancer, six patients had rectal cancer $(30 \%)$ and four patiens had primary cancer located in the right colon $(20 \%)$. The most common site of metastasis was the liver $(75 \%)$ and in three patients it was the only site. Most patients presented with multiple metastases (95\%). Mutation in the RAS gene was detected in $85 \%$ of patients; three patients were RAS wild type. The majority of patients $(80 \%)$ received TT in the third line of treatment, one patient received it in the second line and for three patients (15\%) it was the fourth line or more. The first line irinotecan-based chemotherapy was administered to the majority of patients $(80 \%)$ and four patients received oxaliplatin-based therapy. Thirteen patients $(65 \%)$ received biological therapy. In $60 \%$ of patients time from diagnosis of metastasis to initiation of TT treatment was $\geq 18$ month and in $40 \%$ was $<18$ month. The median number of TT cycles received was 3 (range 1-13),

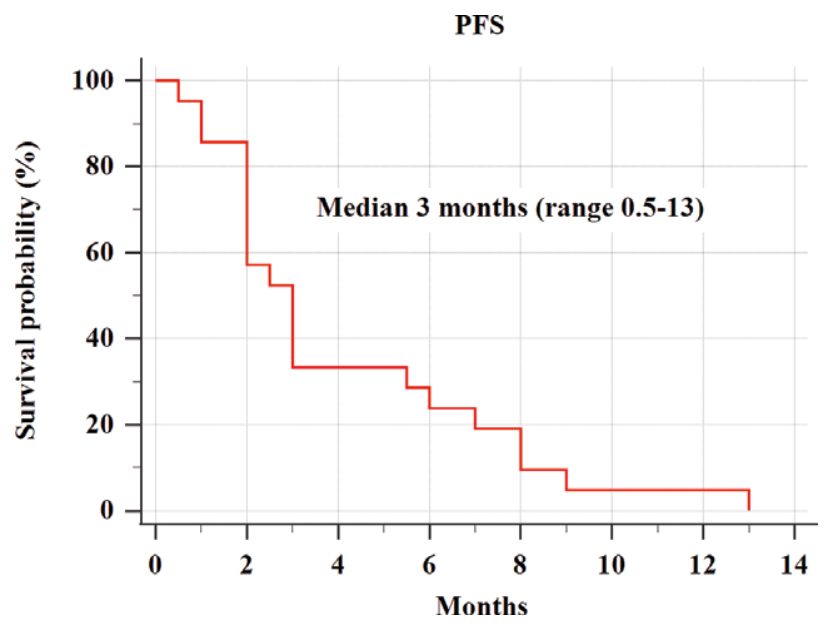

Figure 1. Progression-free survival (PFS) of the study population. The Kaplan-Meier and the log rank tests were used.

and more than one-third of patients (35\%) achieved a therapeutic response; two partial response, and five patients stable disease. Patients characteristics are summarized in Table 1.

All patients progressed and five of them (25\%) died during the follow-up. The median PFS and OS were 3 months (range 2-13) and 6.25 months (range 1-18), respectively, as shown in Figure 1. Male sex (HR 4.45; $\mathrm{p}=0.026)$, better performance status $(p=0.021)$, neutropenia grade $\geq 2$ (HR 5.64; $p=0.013$ ) and positive therapeutic response to TT (HR 12.76; $\mathrm{p}<0.001$ ) were associated with better PFS. There were no significant correlations of PFS with age, previous treatment duration and RAS status ( $p>0.050$ for all analyses). The most common (80\%) side effect of TT was neutropenia; grade 3 in $30 \%$ and grade 4 in $5 \%$ of patients, while neutropenic fever was recorded in only two patients $(10 \%)$. There were no deaths associated with neutropenia.

\section{DISCUSSION}

The improved treatment outcomes in randomized trials are sometimes hard to achieve in everyday clinical practice; thus, observational studies and retrospective analyses are often needed to assess the effects of anti-cancer drugs in the real-life setting. In clinical trials TT demonstrated a beneficial effect on PFS and OS in patients with mCRC refractory to standard chemotherapy(9-15). In randomized phase III clinical trial (RESOURCE) 
TT demonstrated a beneficial effect on progression-free survival (PFS, 2.0 month) and overall survival (OS, 7.1 month) in patients with mCRC refractory to standard chemotherapy. The overall survival benefit with TT was observed in all prespecified subgroups, including subgroups defined according to each of the three stratification factors (i.e., KRAS status, time between first diagnosis of metastases and randomization, and geographic region). In the multivariate Cox regression analysis, none of the factors were identified as being predictive. Three factors were identified as prognostic: time since diagnosis of first metastasis, ECOG performance status, and number of metastatic sites. The most frequently observed clinically significant adverse events (grade 3 or 4 ) associated with TT were neutropenia, which occurred in $38 \%$ of those treated, $4 \%$ of the patients had febrile neutropenia, and one death related to TT was reported $(9,10)$. The TERRA study confirmed that TT has a statistically significant survival benefit compared with placebo in Asian patients with mCRC refractory or intolerant to standard chemotherapies, regardless of exposure to biologic therapy. The safety profile is similar to previous reports(16-18). The primary endpoint in PRECONNECT study was safety. It is ongoing study with 793 patients included. The median duration of treatment was 2.8 months. Drug-related adverse events grade 3 and 4 occurred in $73,9 \%$ of patients. Neutropenia was the most common side effect, with grades 3 and 4 being recorded in $39.1 \%$ of patients. Median time to Eastern Cooperative Oncology Group performance status deterioration $(\geq 2)$ was 8.9 months. There was no clinically relevant change from baseline in quality of life(19-21).

Similarly, these results gathered from a reallife setting seem comparable to those from clinical trials and indicate that refractory $\mathrm{mCRC}$ patients treated with TT in the community setting can have improved clinical outcomes as well. In our study there were no significant correlations of PFS with age, previous treatment duration and RAS status. A possible reason is the small number of patients. On the other hand male sex, better performance status, neutropenia grade $\geq 2$ and positive therapeutic response to TT were associated with better PFS. Lightly lower incidence of neutropenia in our study could be explained with the small number of heavily pretreated patients included in the study.
In conclusion, this study confirmed favourable clinical outcomes of patients with refractory mCRC treated with TT in the real-life setting with manageable toxicities.

\section{REFERENCES}

1. Rawla P, Sunkara T, Barsouk A. Epidemiology of colorectal cancer: incidence, mortality, survival, and risk factors. Gastroenterology Rev 2019;14(2):89-103

2. Šekerija M, Bubanović L, Novak P et al. Croatian Institute for Public Health. Croatian Cancer Registry. Incidence of Cancer in Croatia in 2018. Vol. 43. [Hrvatski zavod za javno zdravstvo. Registar za rak Republike Hrvatske. Incidencija raka u Hrvatskoj 2018., Bilten br. 43], Zagreb, 2020.

3. Van Cutsem E, Cervantes A, Nordlinger B, Arnold D, on behalf of the ESMO Guidelines Working Group: Metastatic colorectal cancer: ESMO Clinical Practice Guidelines for diagnosis, treatment and follow-up. Ann Oncol. 2014;25(suppl 3):III1-III9.

4. NCCN Clinical Practice Guidelines in Oncology. Colon cancer Version 4.2020. Available at: https://www. nccn.org/professionals/physician_gls/pdf/colon.pdf, version 4.2020. Accessed April 23, 2021.

5. Modest DP, Pant S, Sartore-Bianchi A. Treatment sequencing in metastatic colorectal cancer. Eur J Cancer. 2019;109:70-83.

6. Neugut AI, Lin A, Raab GT, Kiran RP, Wrigh J, Hershman DL. FOLFOX and FOLFIRI Use in Stage IV Colon Cancer: Analysis of SEER-Medicare Dana. Clin Colorectal Cancer. 2019;18(2):133-140.

7. Dekker E, Tanis PJ, Vleugels JLA, Kasi PM, Wallace MB. Colorectal cancer. Lancet. 2019 Oct 19;394(10207): 1467-80.

8. Piawah S, Venook AP. Targeted therapy for colorectal cancer metastases: A review of current methods of molecularly targeted therapy and the use of tumor biomarkers in the treatment of metastatic colorectal cancer. Cancer. 2019 Dec 1;125(23):4139-4147.

9. Mayer RJ, Van Cutsem E, Falcone A et al. Randomized trial of TAS-102 for refractory metastatic colorectal cancer. N Engl J Med. 2015;372:1909-1919

10. Van Cutsem E, Mayer RJ, Laurent S et al.; RECOURSE Study Group. The subgroups of the phase III RECOURSE trial of trifluridine/tipiracil (TAS-102) versus placebo with best supportive care in patients with metastatic colorectal cancer. Eur J Cancer. 2018 Feb; 90:63-72

11. Skuja E, Gerina-Berzina A, Hegmane A, Zvirbule Z, Vecvagare E, Purkalne G. Duration of previous treatment as a prognostic factor in metastatic colorectal cancer treated with trifluridine/tipiracil. Mol Clin Oncol. 2018;8(5):699-702.

12. Yoshino T, Mizunuma N, Yamazaki K et al. TAS-102 monotherapy for pretreated metastatic colorectal can- 
cer: A double-blind, randomised, placebo-controlled phase 2 trial. Lancet Oncol. 2012;13:993-1001.

13. Kasi PM, Kotani D, Cecchini et al. Chemotherapy induced neutropenia at 1-month mark is a predictor of overall survival in patients receiving TAS-102 for refractory metastatic colorectal cancer: a cohort study. BMC Cancer. 2016 Jul;16(1):467.

14. Siebenhüner A, Dosso S, Meisel A, Wagner AD, Borner M Metastatic Colorectal Carcinoma after Second Progression and the Role of Trifluridine-Tipiracil (TAS-102) in Switzerland. Oncol Res Treat. 2020;43: 237-244.

15. Iveson T, Carter AM, Shiu KK, Spooner C, Stevens D, Mullamitha S. Review of metastatic colorectal cancer treatment pathways and early clinical experience of trifluridine/tipiracil in the UK named patient programme. BMC Cancer. 2020 Feb;20(1):91.

16. Xu J, Kim TW, Shen L et al. Results of a randomized, double-blind, placebo-controlled, phase III trial of trifluridine/tipiracil (TAS-102) monotherapy in asian patients with previously treated metastatic colorectal cancer: the TERRA study. J Clin Oncol. 2018;36:350-358.
17. Price T, Burge M, Chantrill L et al. Trifluridine/tipiracil: A practical guide to its use in the management of refractory metastatic colorectal cancer in Australia. Asia Pac J Clin Oncol. 2020 Apr;16 (Suppl.1):3-12

18. Chan BM, Hochster HS, Lenz HJ. The safety and efficacy of trifluridine-tipiracil for metastatic colorectal cancer: A pharmacy perspective. Am J Health Syst Pharm. 2019 Feb 21;76(6):339-348.

19. Bachet JB, Wyrwicz L, Price T et al. : Safety, efficacy and patient-reported outcomes with trifluridine/tipiracil in pretreated metastatic colorectal cancer: results of the PRECONNECT study. ESMO Open. 2020;5(3): e000698.

20. Taieb J, Price TJ, Ciardiello et al. Health-related quality of life in the early-access phase IIIb study of trifluridine/tipiracil in pretreated metastatic colorectal cancer (mCRC): results from PRECONNECT study. J Clin Oncol. 2019;37:638.

21. Hamauchi S, Yamazaki K, Masuishi T et al. Neutropenia as a predictive factor in metastatic colorectal cancer treated with TAS-102. Clin Colorectal Cancer. 2017;16:51-57.

\title{
RETROSPEKTIVNA ANALIZA UČINKOVITOSTI I PODNOŠLJIVOSTI TRIFLURIDIN/TIPIRACILA U BOLESNIKA S REFRAKTORNIM METASTATSKIM KOLOREKTALNIM KARCINOMOM U OPĆOJ BOLNICI ŠIBENSKO-KNINSKE ŽUPANIJE
}

\author{
L. Jajac Bručić, F. Grubišić-Čabo, J. Jović Zlatović, I. Krečak
}

U randomiziranim kliničkim studijama trifluridin/tipiracil (TT) je pokazao povoljan učinak na preživljenje bez progresije bolesti (PFS) i na ukupno preživljenje (OS) u bolesnika s refraktornim metastatskim kolorektalnim karcinomom (mKRK). Cilj ovog unicentričnog istraživanja bio je procijeniti učinkovitost i sigurnost primjene TT kod bolesnika s refraktornim mKRK u svakodnevnoj kliničkoj praksi. Retrospektivno su analizirani ishodi liječenja 20 bolesnika. Medijan OS bio je 6.25 mjeseci (raspon 1-18) a medijan PFS 3 mjeseca (raspon 2-13). Najčešća (80\%) nuspojava TT bila je neutropenija, u 35\% bolesnika gradusa 3 i 4. Ipak, u samo dva bolesnika (10\%) zabilježena je neutropenična vrućica, a nijedan bolesnik nije preminuo zbog neutropenije. Zaključno, ishodi liječenja bolesnika s mKRK s TT u svakodnevnom kliničkom radu usporedivi su s onima iz randomiziranih kliničkih studija.

KLJUČNE RIJEČI: refraktorni metastatski kolorektalni karcinom; liječenje kolorektalnog karcinoma; trifluridineltipiracil 